\title{
A Study on Inclusive Education in Turkey*
}

\begin{tabular}{ccc}
\hline $\begin{array}{c}\text { Article Type } \\
\text { Research }\end{array}$ & $\begin{array}{c}\text { Received Date } \\
5.11 .2019\end{array}$ & $\begin{array}{c}\text { Accepted Date } \\
21.07 .2020\end{array}$ \\
\hline Tamer Sarı $^{* *}$ & Funda Nayir $^{* * *}$ & Ümit Kahraman $^{* * * *}$
\end{tabular}

\begin{abstract}
The purpose of this research is to examine inclusive education research and to guide applications and research according to the results obtained. Within the framework of this aim, the studies carried out in the field of inclusive education in Turkey were systematically examined. Articles published in national and international refereed journals in English or Turkish between 2009-2019 were included in the research The research is qualitative research in which the studies are examined according to the publication year, publication language, subject, research design, the field of the researchers and the scope of the articles. The data of the study were collected through document review. In this study, it has been concluded that the studies about inclusive education have started to increase in recent years, generally, qualitative research methods are used and more specifically, researchers in special education field have made inclusive education studies. When the articles were examined in terms of scope, it was seen that the majority of the studies were on attitude and descriptive studies. At this point, it can be said that the priority of the studies related to inclusive education in Turkey is not to produce theoretical knowledge or to create the infrastructure of new studies by examining the studies done. In the studies carried out, studies that reveal the opinions, attitudes and perceptions of the participants regarding inclusive education were more prominent. In order to contribute to both national and international literature, it would be useful to conduct further research on theoretical and literature research and to plan experimental research to reveal the effectiveness of inclusive education-related practices. Similar studies will be conducted in different countries and the comparison of the findings will contribute to the literature in terms of revealing the international trend.
\end{abstract}

Keywords: inclusive education, individual differences, cultural differences, education for each student.

\footnotetext{
* This study is an extended version of the paper presented at the 14th Education Management Congress held in Çeşme between 2-4 May 2019.

${ }^{* *}$ Dr., Pamukkale University, School of Foreign Languages, Denizli, Turkey. E-mail: tamersari@ pau.edu.tr, https://orcid.org/ 0000-0003-3752-9277

**** Assoc. Prof., Pamukkale University, Education Faculty, Educational Sciences, Denizli, Turkey. E-mail: fnayir@pau.edu.tr, https://orcid.org/0000-0002-9313-4942

***** Corresponding Author: Assist. Prof., Bilecik Şeyh Edebali University, Faculty of Health Sciences, Child Development, Bilecik, Turkey. E-mail: ukahraman8364@gmail.com, https://orcid.org/0000-0002-4547-6753
} 


\section{Türkiye'de Kapsayıcı Ĕgitim Üzerine Bir Çalışma*}

\begin{tabular}{ccc}
\hline $\begin{array}{c}\text { Makale Türü } \\
\text { Araştırma }\end{array}$ & $\begin{array}{c}\text { Başvuru Tarihi } \\
5.11 .2019\end{array}$ & $\begin{array}{c}\text { Kabul Tarihi } \\
21.07 .2020\end{array}$ \\
& & \\
Tamer Sarı $^{* *}$ & Funda Nayır $^{* * *}$ & Ümit Kahraman $^{* * * *}$ \\
& & \\
Öz &
\end{tabular}

$\mathrm{Bu}$ araştırmanın amacı, kapsayıcı eğitim araştırmalarının incelenmesi ve elde edilen sonuçlar doğrultusunda uygulamalara ve araştırmalara yön verilmesidir. Bu amaç çerçevesinde Türkiye'de kapsayıcı eğitim alanında yapılan çalışmalar sistematik olarak incelenmiştir. 2009-2019 yılları arasında ulusal ve uluslararası hakemli dergilerde İngilizce ve Türkçe olarak yayınlanan makaleler araştırma kapsamına alınmıştır. Araştırma, çalışmaların yayın yılı, yayın dili, konusu, araştırma deseni, araştırmacıların alanı ve makalelerin kapsamına göre incelendiği nitel bir araştırmadır. Araştırmanın verileri doküman incelemesi yoluyla toplanmıştır. Çalışmada, kapsayıcı eğitim hakkında yapılan çalışmaların son yıllarda artmaya başladığı, genellikle nitel araştırma yöntemlerinin kullanıldığı ve daha çok özel eğitim alanındaki araştırmacıların kapsayıcı eğitim çalışmaları yaptığı sonucuna ulaşılmıştır. Makaleler kapsam açısından incelendiğinde yapılan çalışmaların büyük çoğunluğunun tutum araştırmaları ve tanımlayıcı araştırmalar olduğu görülmüştür. Bu noktada Türkiye'de kapsayıcı eğitim ile ilgili yapılan çalışmaların önceliğinin kuramsal bilgi üretmek ya da yapılmış çalışmaları inceleyerek yeni çalışmaların altyapısını oluşturmak olmadığını görülmektedir. Yapılan çalışmalarda öne çıkan eğilim kapsayıcı eğitime ilişkin olarak katılımcıların görüşlerini, tutumlarını ve algılarını ortaya çıkaran çalışmalar daha ön plandadır. Gerek ulusal gerekse uluslararası alanyazına katkı sağlamak için kuramsal ve alanyazın taraması araştırmaların daha fazla yapılması, kapsayıcı eğitim ile ilgili uygulamaların etkililiğini ortaya çıkarmak için deneysel araştırmaların planlanması yararlı olacaktır. Benzer çalışmanın farklı ülkelerde yapılması ve bulguların karşılaştırılması da konu ile ilgili uluslararası eğilimi ortaya çıkarması açısından alanyazına katkı sağlayacaktır.

Anahtar Sözcükler: Kapsayıcı eğitim, bireysel farklılıklar, kültürel farklılıklar, her öğrenci için eğitim.

\footnotetext{
* Bu çalışma 2-4 Mayıs 2019 tarihleri arasında Çeşme'de düzenlenen 14. Eğitim Yönetimi Kongresi'nde sunulan bildirinin genişletilmiş halidir.

** Dr., Pamukkale Üniversitesi Yabancı Diller Okulu, Denizli, Türkiye. E-posta: tamersari@pau.edu.tr, https://orcid.org/ 00000003-3752-9277

**** Doç. Dr., Pamukkale Üniversitesi Eğitim Fakültesi Eğitim Bilimleri Bölümü, Denizli, Türkiye. E-posta: fnayir@pau.edu.tr, https://orcid.org/0000-0002-9313-4942

*** Sorumlu Yazar: Dr. Öğr. Üyesi, Bilecik Şeyh Edebali Üniversitesi, Sağlık Bilimleri Fakültesi, Çocuk Gelişimi Bölümü, Bilecik, Türkiye. E-posta: ukahraman8364@gmail.com, https://orcid.org/0000-0002-4547-6753
} 


\section{Introduction}

Inclusive education has begun to take place as an important concept in the education policies of all countries in recent years. It can be said that the increase in the importance given to human rights and the fact that education is the fundamental right of all people is effective on the basis of this interest. In fact, the Expression "Everyone has the right to education" in the United Nations Universal Declaration of Human Rights (1948) also emphasizes that education is a fundamental right. This right is also secured with the Constitution of Turkey (1982). In accordance with Article 42 of the Constitution of the Republic of Turkey: "No one shall be deprived of education and training". The right of education to all individuals without discrimination raises the issue of equality of opportunity in education and the fact that all individuals should benefit from education services equally.

When the history of inclusive education is examined, it is seen that it is primarily considered as an education service provided to individuals with special needs. In ancient times, individuals with special needs were believed to be burdens and these individuals were removed from society (dehumanization). With the advent of heavenly religions, religious beliefs played an important role in approaches to individuals with special needs, and the idea of protecting these individuals was adopted (protection). In the 1600 s, these individuals were excluded from the society again (exclusion), and by the 1800 s, schools were opened for these individuals. By the 1900s, segregation approach was adopted and these individuals were provided with education in environments designed separately from the general education environment (segregation). In the 1960s, the approach of normalization (normalization) was adopted and the idea that these individuals receive education in normal settings as much as possible was accepted. 1970s were the years when the least restrictive environment approach was adopted (Yücesoy Özkan, Kırkgöz and Beşdere, 2019) (least restrictive environment). The least restrictive environment is the environment where individuals with special needs can receive education in the same environments with their families and peers and the educational needs can be met in the best way (Kurcaali İftar and Batu, 2005). The least restrictive environment also formed the basis of the mainstreaming education that emerged in the 1980s (mainstreaming). In this period, while the inclusion perception expresses the participation of the students in the general classroom activities, it is expressed as ensuring equal opportunities for the students to perform at the highest level (Yücesoy Özkan, Kırkgöz and Beşdere, 2019). In the 1990s, this turned into an integration approach in which, in light of the equal opportunity, all the things that could be done for students to progress in general education classes were discussed and support services were at the forefront (integration). Education for all in the 2000s has been a global movement aimed at enabling all individuals to benefit from basic education and meeting their educational needs (UNESCO, 2000). This movement turned into an inclusive education approach in 2010's (Alquraini and Gut, 2012). At this point, inclusive education is the education given in accordance with their age in general education environments with their peers by providing support and socialization for all students to be successful (Alquraini and Gut, 2012). In other words, inclusive education is the focus of all students who are excluded because of their differences in a way to cover the whole school (Gürgür, 2019).

The meaning of equal opportunity in education is that it has educational opportunities according to the needs of individuals rather than mathematical equality (Yllmaz and Sarpkaya, 2017). Equality of opportunity in education can be fulfilled by organizing education to cover all individuals. At this point, the concept of inclusive education gains importance. Booth and Ainscow (2002) describe the philosophy of inclusive education as the physical conditions of schools are not tailored to the needs of the students with special needs, but all components of the education are adapted to the mainstream process, and the educational programs are restructured so that every child feels like part of the class.

Inclusive education is the process of strengthening the capacity of the education system to reach out to all students (UNESCO, 2009a) and it has emerged with the aim and effort to eliminate / compensate for the deficiencies of a discriminatory educational entity. Meeting educational needs of students is part of the development of fair provisions in an inclusive society where individual rights are recognized and protected (OECD, 2003). The emergence of the institution (Ünal, 1996), which will carry out this education, can be seen as an indicator of production-based education at a time when it is no longer possible to transfer the knowledge and culture which are increasing more and more thanks to social and technical developments to new generations by using the same technics such as, the master- 
apprentice relationship method. Education, defined as the process that gives the individual the desired behaviour, knowledge, skill and quality (Adem, 2008), can be defined as the investment in human beings (Marshall, 1920) considered to be the most valuable of the capital for the civilization. Since direct contribution to production is seen as the main purpose, it can be said that those who have different characteristics are ignored when compared to those who have mainstream characteristics. This neglect manifests itself as the first discrimination of education and the elimination of this discrimination has only begun in the last 30 years (Amor et al., 2018). However, only physical barriers may not be indicative of specific needs. While inclusive education is closely related to the right to education for children with disabilities, it is not only limited to the right to education of children in this group, but it is a necessary approach for the provision of the right to education for all children who are disadvantaged for different reasons (UNICEF, 2011). This requires education to protect students against gender, language, religion, disability and racial discrimination, to take account of these differences and to make sure that all individuals benefit from education services equally. In this context, it can be said that the basic idea of inclusive education is to ensure equality of opportunity in education.

The acceleration of inclusive education activities was carried out in 1994 together with the "Conference on Special Needs Education", "Access and Quality" conducted in Spain with more than 300 participants representing 92 governments and 25 international organizations (UNESCO, 2009a). In addition, in 2015, the meeting held in New York was determined as one of the goals of sustainable development, to provide inclusive and fair quality education and to promote opportunities for lifelong learning for all (OECD, 2016). All these developments have been one of the most powerful driving forces in changing education policies and practices worldwide in recent years (Deng, Wang, Guan and Wang, 2017).

In inclusive education, stereotype insulating special education system should be eliminated and schools need to be more accessible and more sensitive to students with different learning needs to ensure quality education rights (UNESCO, 2009b). Accordingly, inclusive education can be defined as the response process by increasing the participation of all learners, cultures and communities, increasing participation in learning and reducing discrimination within the education system (Düşkün, 2016). In order to achieve this process, inclusive education should provide local schools for all children regardless of any perceived differences, disabilities or other social, emotional, cultural or linguistic differences (Florian, 2008).

The national legislation in Turkey, especially the education of children with a disability, is regarded to be compatible with international legislation (Düşün, 2016). Turkey is a signatory to the Convention on the Rights of the Child (1989), legislation by signing the United Nations Convention on the Rights of Persons with Disabilities in 2006 and practices in the prevention of discrimination and has taken on the responsibility of troubleshooting, moreover, Turkey made the arrangements for special needs individuals education services in 1997, the Turkish Ministry of National Education (MoNE) has been influential in the development of policies for the education of children with disabilities and special needs. However, it is difficult to say that it is equally comprehensive in terms of gender, language, religion and ethnicity. Although comprehensive education projects (MoNE Inclusive Education Project 2016-2018) have been conducted in recent years especially for Syrian migrants, discrimination based on gender has been prohibited in the Constitution and many other regulations, however, comprehensive arrangements have not been made to make the education environments inclusive for girls and children with different sexual orientations (Düşkün, 2016). However, according to the approaches that consider inclusive education as part of human rights and participatory democracy (eg, Barton, 1995; Polat, 2011), it is not possible for policy makers, administrators, teachers, normally developing students and parents to reach the goals of inclusive education as long as their thoughts and attitudes towards inclusive education are not evaluated from the social justice and diversity framework (www.herkesicineğitim.org). Having regulations in legislation does not mean that problems will be solved or resolved. In order to solve the problems in general, the school administrators and teachers should be informed and the applications should be monitored. In addition, the families who are responsible for the care and education of their children need to be informed and applications should be carried out by taking the opinions of the parents about what can be done for the continuation of the education life of the students. 
Studies on inclusive education have shown that there are more studies based on students with disability in Turkey. In recent years, the studies on the concepts such as language, religion, ethnic origin can be said to have increased. When these studies are examined, it can be said that there is also a methodological diversity. In some studies, it is found that various research methods and the difficulties faced by disadvantaged students are included; other studies, it is observed that the curriculum and textbooks are examined. It is emphasized that one of the most important stakeholders of inclusive education are teachers and the attitude of teachers towards inclusive education (Düşkün, 2016). At this point, it is thought that examining the researches about inclusive education will guide the practitioners by revealing the perception about inclusive education and the tendency in these researches. In this context, the aim of this study is to examine the articles on inclusive education in Turkey between 20092019 and published in international refereed journals in English or Turkish according to different variables. In this respect, the answers to the following questions have been sought.

1) What is the distribution of the articles according to years and the language of publication?

2) What is the distribution of the articles according to the subject content?

3) What is the distribution of the articles according to the research design?

4) What is the distribution of articles according to the fields of researchers?

5) What are the articles classified by type?

\section{Method}

The aim of the study was to examine the studies in the field of inclusive education in Turkey by publication year, publication language, publication topic, research pattern, the fields of the researchers and the types of the articles, therefore qualitative approach was used in the study.

\section{Limitations of the study}

The research is limited to Turkish and English articles published in international journals in the last decade (2009-2019) with the words "inclusive education" / "kapsayıcı eğitim" in the title, abstract or keywords of the articles or the content of the article. The selected articles were examined one by one and the studies that were not covered by inclusive education words in the title of the article, abstract or keywords, or which were not related to content education applications of the article were excluded from the scope of the study.

\section{Data Collection Tool}

The data of the study were collected through document review. The document review covers the analysis of written materials that contain information about the requested phenomenon or facts. In this kind of research, the researcher can obtain the data he/she needs without having to observe or interview. In this type of analysis, what kind of documents can be used as a data source is determined according to the research problem. Document review makes it possible to analyse a research problem in a time frame based on documents produced within a certain time frame or documents produced in more than one source and at different intervals in relation to a research problem (Yıldırım and Şimşek, 2013). In this respect, the articles that were completed between 2009 and 2019 and which meet the definitions defined in the limitations of the study were examined.

ERIC, EBSCO, Google Scholar and ULAKBIM search engines were used to reach the articles included in the research. The term "inclusive education" / "kapsayıc1 eğitim" as a keyword in the search section is written and the results are listed by three separate researchers. The process of inclusion of articles that are decided by the criteria determined by the search engines is shown in Figure 1. 

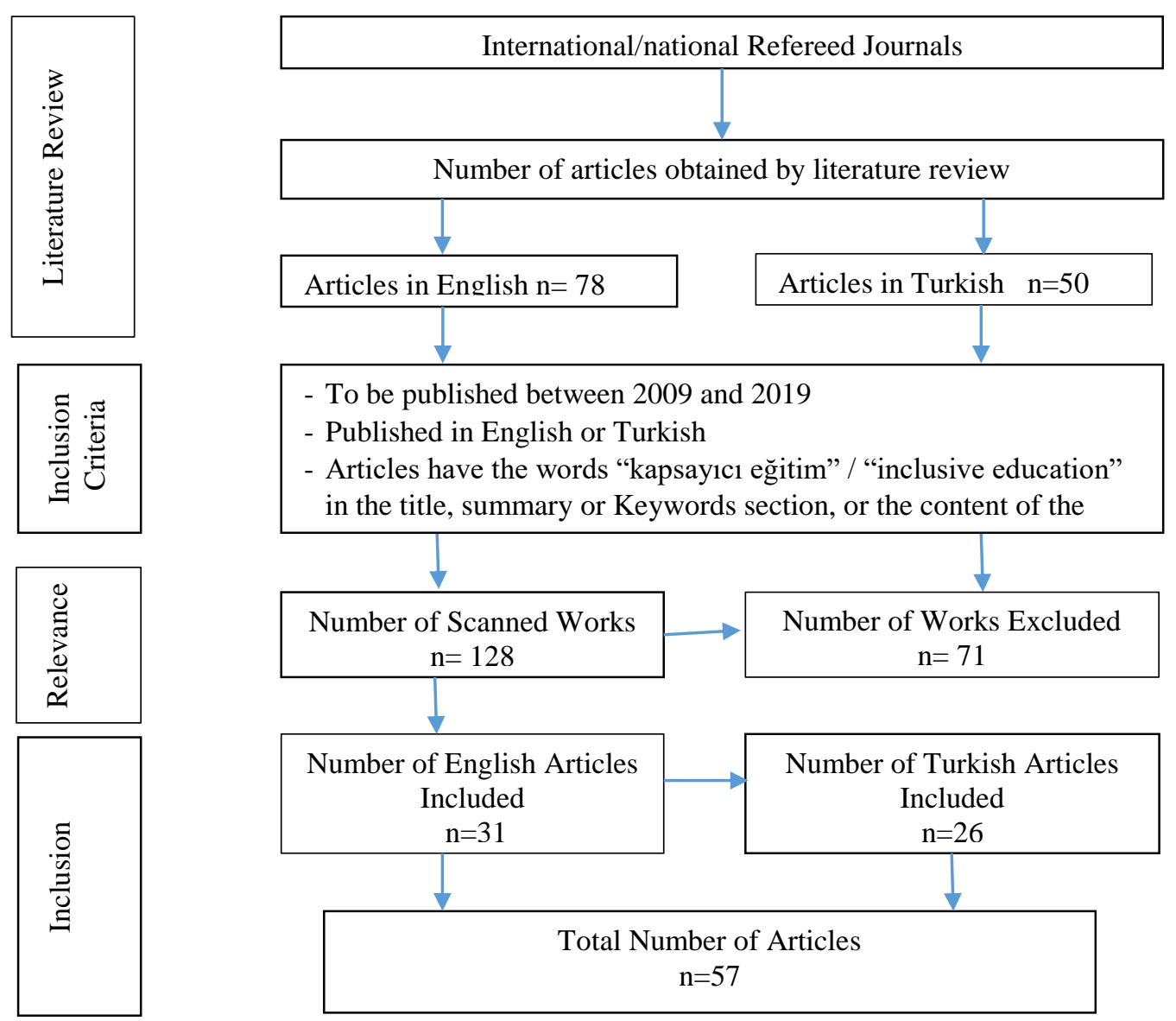

Figure 1. The process of including articles in the research process

As shown in Figure 1, Turkish and English articles published in national and international refereed journals were discussed in 2009-2019 in order to find out how inclusive educational studies are progressing in Turkey. In this context, 78 English and 50 Turkish articles were reached first. At this point, a total of 128 articles were examined and 71 articles were excluded which did not meet the criteria of inclusion. As a result, a total of 57 articles, 31 in English and 26 in Turkish, were included in the study.

\section{Data Analysis}

Content analysis was used in data analysis. Themes have been created for the articles studied within the scope of the research. The related categories are discussed as attitudinal, descriptive, theoretical, literature review and Intervention. Definitions related to themes are given in Table 1. 


\section{Table 1}

Definitions of article categories

\begin{tabular}{ll}
\hline Category & Description \\
\hline \multirow{2}{*}{ Attitudinal } & $\begin{array}{l}\text { Articles focused on understanding the attitudes and/or perceptions of different stakeholders } \\
\text { in regard to inclusive education. Typically, these articles report findings from quantitative } \\
\text { and/or qualitative data collection }\end{array}$ \\
& $\begin{array}{l}\text { Articles that describe based on quantitative and/or qualitative data, the current status of } \\
\text { inclusive education in a school, community, or country. The goal of the analysis can be to } \\
\text { describe current conditions or barriers for success. Studies examining the current status of } \\
\text { inclusive education (e.g. number of students included in a given context) were categorised } \\
\text { into this category. }\end{array}$ \\
& $\begin{array}{l}\text { Articles providing rationale for inclusive education based on existing or developing theory. } \\
\text { This could be applied at the level of country-wide policy development or local policies in }\end{array}$ \\
& $\begin{array}{l}\text { schools or communities, as well as by theoretically-driven frameworks for developing } \\
\text { professional development related to inclusive education. }\end{array}$ \\
Literature & Articles describing findings from a literature review or meta-analysis about inclusive \\
reviews & education. The specific focus was on synthesising existing research related to inclusive \\
& education \\
Intervention & Articles that reported data on student-level outcomes as a result of the implementation of \\
inclusive practice. The 'intervention' could include models of inclusive education or \\
specific practices implemented in an inclusive setting.
\end{tabular}

Source: Amor et al. (2018).

As seen in Table 1, attitudinal studies are the studies aimed at revealing the attitudes and perceptions of the participants about inclusive education. Descriptive studies are studies aimed at revealing existing practices and situation related to inclusive education. Theoretical studies are studies to develop theories and policies for inclusive education. Theoretical studies are studies to develop theories and policies for inclusive education. Literature survey is the study in which the findings of studies related to inclusive education are interpreted based on literature. Intervention studies are studies in which the results of an application for inclusive education are evaluated (Amor et al. 2018). Then the articles were classified according to the publication language and publication year, and the research pattern, the field of the researchers and the research sample were coded separately in each article.

\section{Validity-Reliability}

In qualitative research, trustworthiness is used instead of validity and reliability is based on credibility, transferability, dependability and confirmability criteria (Guba and Lincoln, 2005). Creswell (2003) states that one or more of these criteria should be specified. In this study, credibility and transferability criteria are taken as basis. Credibility is related to the internal validity of the research and is related to the fact that the findings are compatible with the reality (Meriam and Tisdell, 2005). In this study, credibility between encoders and matching with previous research (Amor et al., 2018) findings were used for trustworthiness. For this purpose, the coding was done by the researchers separately and the goodness percentage was calculated. Miles and Huberman's (1994) formula were used and $91.75 \%$ calculated as the percentage of agreement. In addition, the results of the research were compared and interpreted with other research findings in the literature. The transferability of the research is related to external validity (Guba and Lincoln, 2005). The method used in the research, how the data is encoded, the inclusion and exclusion criteria are elaborated in detail.

\section{Results}

The findings obtained in accordance with the purpose of the study were examined using graphics and word clouds. Figure 2 shows the distribution of the work done according to years. 


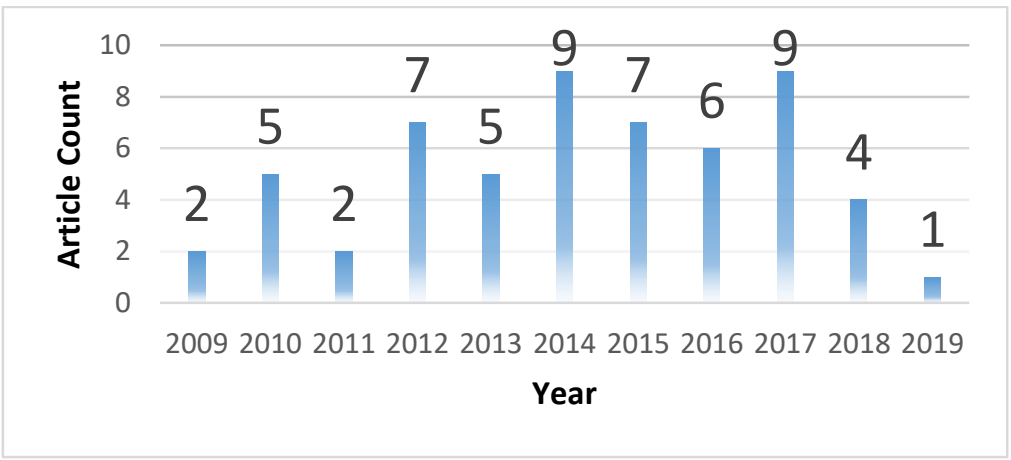

Figure 2. Distribution of articles by year of publication

When the distribution of the articles according to the publication years is shown in Figure 2, it is observed that the studies mostly conducted between 2014 and $2017(\mathrm{n}=32 ; 15.8 \%)$. When the table is examined in general, there are 21 studies between the years 2009-2013. Between 2014-2019, 36 studies were conducted. Accordingly, it can be said that in recent years, studies on inclusive education have increased.

The distribution of the studies according to the language of publication is given in Figure 3.

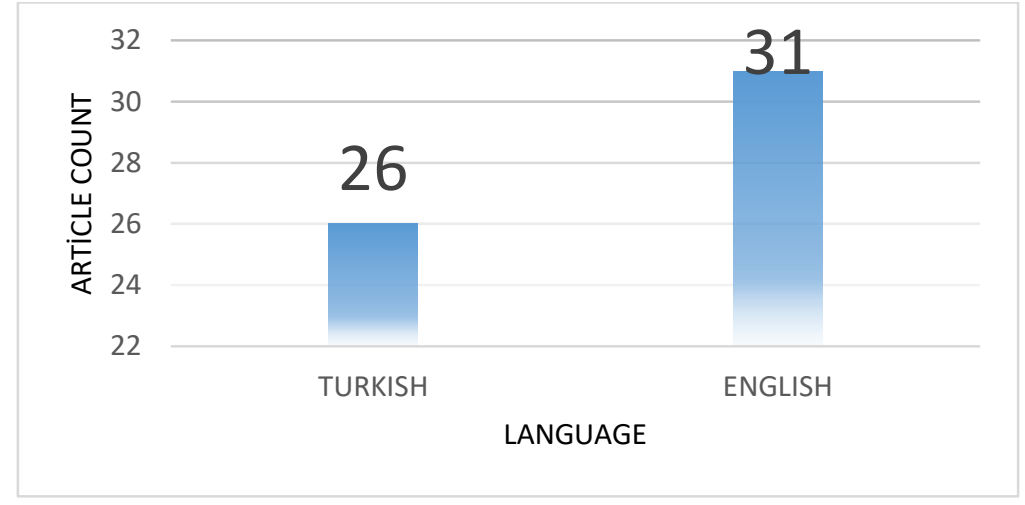

Figure 3. Distribution of articles by language of publication

According to the distribution of the Articles showing in Figure 3, 31 of the studies (54.4\%) were prepared in English; 26 (45.6\%) were prepared in Turkish. In agreement with the results, it can be said that the studies were mostly conducted in English. The contents of the studies discussed within the scope of the research are given in Figure 4.

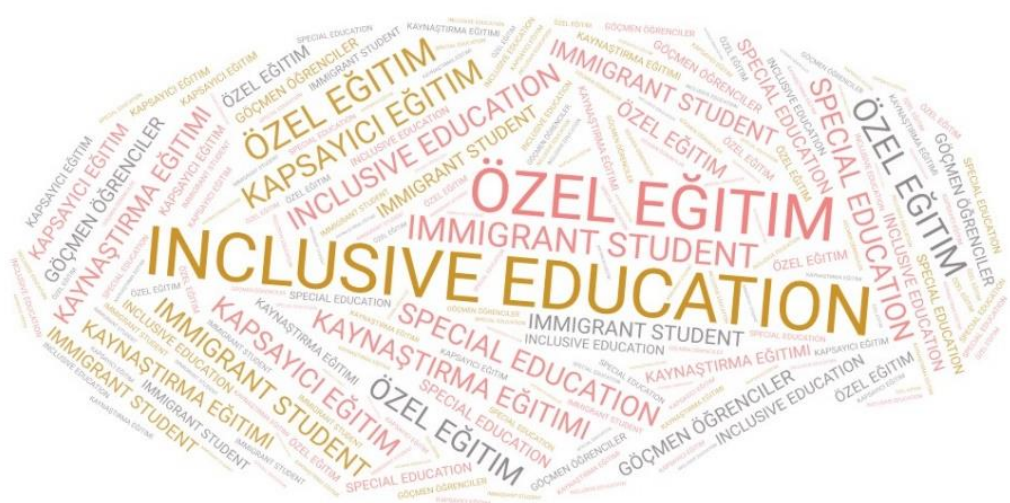

Figure 4. Word cloud related to the subject content of inclusive education work 
Figure 4 is the word cloud showing the classification of the researches by subject content. When the contents of the studies were examined, it was perceived that inclusive education research focused more on mainstream education $(n=31 ; 54.4 \%) .15$ of the studies were studied in special education and 7 in migrant students. Lastly, 4 of the researches are the studies covered within the scope of inclusive education.

The findings of the research design of the articles are given in Figure 5.

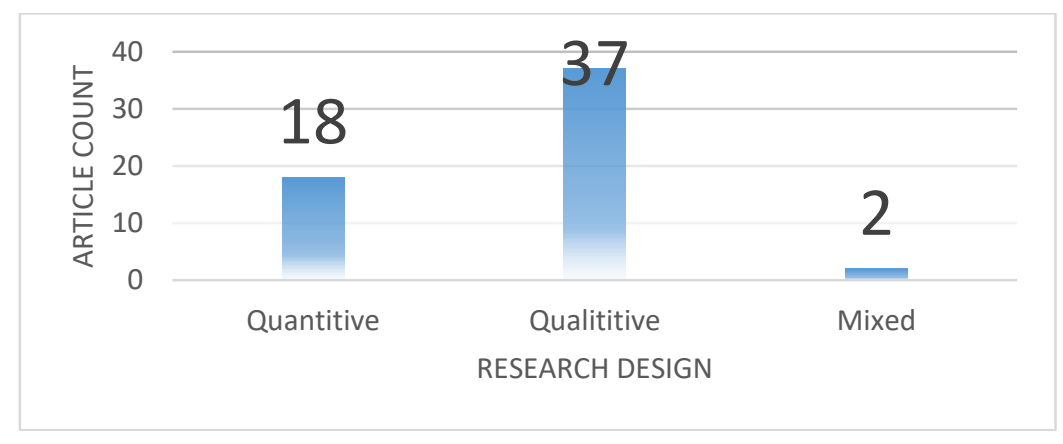

Figure 5. Distribution of articles by research design

When the distribution of the articles according to the research designs is shown in Figure 5, it can be said that the most qualitative research design $(n=37 ; 64.9 \%)$ was performed. 18 of the studies were quantitative (31.6\%) and $2(3.5 \%)$ were in mixed research design. It can be said that studies related to inclusive education are mostly carried out in qualitative research design. Qualitative research may be more likely because inclusive education is broad on the subject area (such as special education, individuals with special needs, migrant students) and because inclusive education practices need to be examined in more depth. Mixed method research is rarely encountered. Mixed method research may be less used because it requires both qualitative and quantitative research skills.

The results of the study areas of the researchers are given in Figure 6.

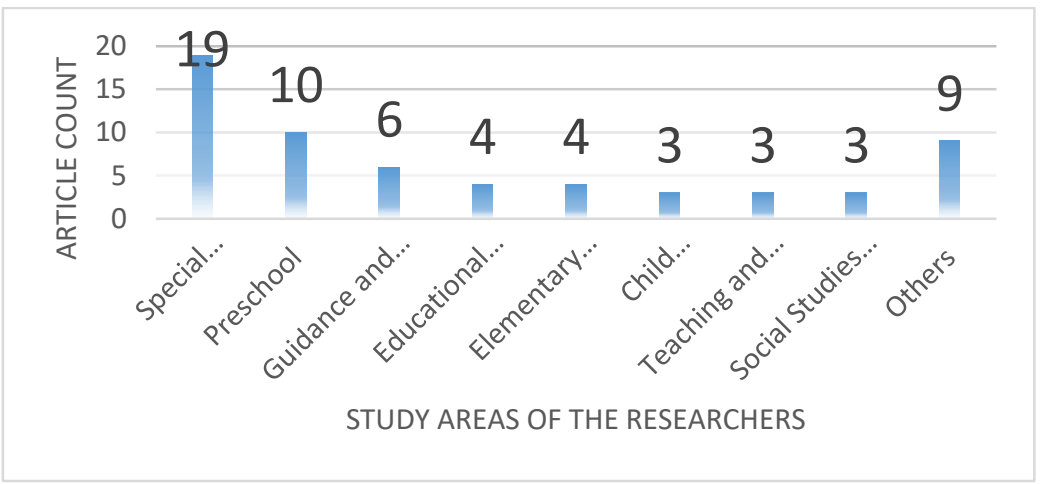

Figure 6. The results of the study areas of the researchers

Figure 6 shows that the researchers in the field of special education $(\mathrm{N}=19 ; 31.1 \%)$ conducted studies on inclusive education mostly. This is followed by 10 studies (16.4\%) in Preschool Education and 6 studies (9.8\%) in Psychological Counselling and Guidance. 4 of the researchers in the field of Education Administration and Primary Education each, 3 of the researchers in the field of Child Development, Educational Programs and Social Studies Education have been found. 9 of the researchers are in other fields (Political Science and Public Administration, Architecture, Educational Psychology, etc.). When the graphs are examined in general terms, it is figured out that inclusive education activities are carried out in a wide range of areas and outside the education area. However, it can be said that Educational Administration researchers, who are expected to carry out studies on the development of educational policies, conducted relatively few studies on inclusive education. 
The results related to the classification of the articles are given in Figure 7.

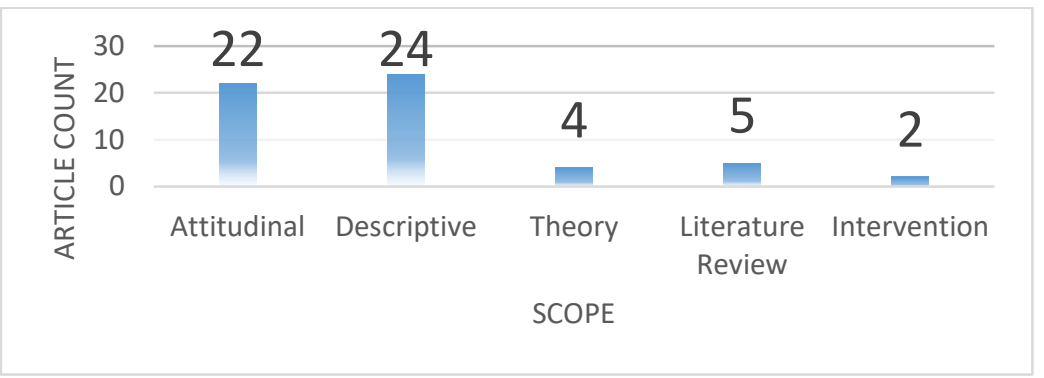

Figure 7. Distribution of articles by scope

In Figure 7, it can be seen that the vast majority of inclusive education articles are based on attitudinal research $(\mathrm{n}=22 ; 38.6 \%)$ and descriptive research $(\mathrm{n}=24 ; 42.1 \%)$. Five of the articles were literature review $(8,8 \%)$ and 4 were theoretical $(7 \%)$. Only 2 of the studies were intervention studies $(3.5 \%)$.

\section{Discussion, Conclusion and Recommendations}

In this research, 57 studies, 26 of them in Turkish and 31 in English, were carried out in the scope of "inclusive education" or "kapsayıcı eğitim" in the title or keywords between the years 2009-2019. When years of research are examined, it is concluded that that 1 article in 2019; 2 articles in 2009 and 2011; 4 articles in 2018; 5 articles in 2010 and 2013; 6 articles in 2016; 7 articles in 2012 and 2015; and 9 articles in 2014 and 2017. In general, it is observed that the studies towards inclusive education increased between the years 2014-2019. This may be due to the recent legal regulations on education in Turkey and the increase in the number of migrants in Turkey. In this respect, it is affirmed that education policies of countries have an effect on education researches.

When the articles are examined according to the language of publication, it is stated that there are more articles published in English. Amor et al. (2018) revealed that more studies in English on inclusive education were published between 2002 and 2016. This may be due to the fact that English is preferred more as a Lingua Franca and the international access rate is high, so studies can reach more readers and increase the chance of citation.

When the scopes of the articles are considered, it is understood that it is mostly related to the mainstream students, special education and immigrant students. In this case it can be interpreted as inclusive education is considered as a concept for the training of more disadvantaged groups in Turkey and this is not true only for Turkey. Amor et al. (2018), Messiou (2017), Nilholm and Göransson (2017) also revealed that inclusive education is generally addressed for students with disability. Although inclusive education is considered for groups with disability/disadvantage, it is an education that aims to meet all students' and academic achievements (Ainscow, Booth and Dyson, 2006; UNESCO, 2008; Nilholm and Göransson, 2017). However, the increased migration figure in Turkey in recent years may be the reason for the increase in the study of migrants in the context of inclusive education. As of 2018, there are approximately 4.3 million refugees from many different countries (Iraq, Afghanistan, Iran and Somalia, mainly Syria). Considering only those coming from Syria, $50 \%$ of the migrants arriving are under 18 and the schooling rate at primary level is 95\% (Migration and Compliance Report, 2018). This requires the integration of immigrant students into the education system and includes many difficulties (European Commission, 2019). In this case, it is possible to say that immigrant students are considered as disadvantaged groups and included in inclusive education.

When the research design used in the articles is examined, it is seen that qualitative research is more preferred. The qualitative research focuses on the status of individuals in the world (Patton, 2015), and an interpretative study based on the examination of individuals in specific situations in their natural environment (Denzin and Lincoln, 1994). The interpretive approach is an approach that focuses on how individuals perceive the world (Robson and McCartan, 2016), trying to uncover the reality underlying the action (Kaya, 2019), and aims to reveal the meanings attributed to individuals by understanding the events (Keat and Urry, 2010). It is possible to say that qualitative research has been carried out in order 
to present the meanings loaded by individuals on the events more deeply, based on the findings that the studies related to inclusive education are concentrated on individuals with disability/disadvantage and immigrant students. In addition, individuals with disability/disadvantage and immigrant students may be considered as the case and qualitative research may be preferred to reveal the perceptions of this phenomenon.

When the articles are examined, it can be said that the researchers in the field of special education are mostly involved in inclusive education. As a result of the consideration of the disability and disadvantaged groups (Amor et al., 2018) in relation to inclusive education, it is generally expected that special education researchers should study on this issue. It can also be said that the use of special education and inclusive education in the regulations published by the MoNE in 1997 and 2006 is effective in the formation of this perception.

Considering the types of articles, attitudes and descriptive researches are seen to be clearly ahead, similar findings have also been obtained in the project "education for all" funded by the European Union and of which Turkey is a partner. According to this, when the literature on inclusive education in Turkey is scanned, it is observed that the attitudes of teachers and teacher candidates towards it are measured in most of these studies. These studies, which are useful in describing the current situation of coverage, repeat each other in a methodological way. In addition, research questions and empirical results were asked and interpreted without any theoretical framework (http://www.herkesicinegitim.org). Literature review is a summary of previous research on the subject. Theoretical studies are carried out to test existing theory or knowledge and to create a new one (Ekiz, 2013). At this point, it is observed that the priority of the studies related to inclusive education in Turkey is not to produce theoretical knowledge or to create the infrastructure of new studies by examining the studies done. The main trend in the studies is that studies that reveal the opinions, attitudes and perceptions of the participants in relation to inclusive education are more prominent. However, the main purpose of a scientific study is to produce knowledge and to create new ideas by using existing knowledge. This situation is not peculiar to Turkey. In their study on inclusive education, Nilholm and Göransson (2017) found that the most empirical studies were carried out and were followed by the position paper discussing and evaluating the subject. Amor et al. (2018) found that theoretical studies related to inclusive education were more prevalent and followed by descriptive studies. At this point, it is possible to say that there is a different trend regarding the type of studies carried out on inclusive education in Turkey. Descriptive and behavioural studies based on data reporting take precedence in Turkey. This may be due to the fact that descriptive and attitudinal work is more methodically easier. However, for scientific progress, it is necessary to go beyond the problem and possible analyses (McCart, Sailor, Bezdek, and Satter. 2014).

In conclusion, in this study, it was aimed to reveal the trends related to the research on inclusive education in Turkey. For this purpose, articles published in national and international peer-reviewed journals were examined. According to the research findings, studies on inclusive education in Turkey have been increasing in recent years. Qualitative research pattern and English language are preferred more frequently in the articles. The articles were mostly conducted in the special education area and students with disabilities/disadvantaged and migrant students were investigated. Considering the type of articles, it is concluded that descriptive and attitudinal research containing data reporting is more preferred.

In this study, the perceptions of inclusive education in Turkey were found to be limited to students with disability/disadvantage students, special education students, and immigrants. For this reason, it is recommended to extend the scope of research in different disciplines by considering inclusive education for all students. Moreover, it may be said that more studies are required in the Turkish language, since more studies in the English language might reduce accessibility at the national level. The increase in studies on inclusive education in recent years is a positive result. This can be attributed to national and international legal regulations on education. In this respect, it can be suggested that countries should refer to inclusive education more in the legal regulations related to education policies. The studies are mainly done in qualitative research designs and this is followed by quantitative studies.

However, it is an important finding that the number of mixed researches is very low. Mixed research is a method that extends the understanding of the individual about the event where qualitative 
and quantitative methods are combined and the advantages of both patterns are used where researchers can use multiple methods and data collection techniques (Onwuegbuzie and Leech, 2004). At this point, it would be useful to use more of the mixed method in researches about inclusive education. Another important result in the study is that there are more descriptive and attitudinal studies based on data reporting.

In order to contribute to both national and international literature, it would be useful to conduct further research on theoretical and literature research and to plan experimental research to reveal the effectiveness of inclusive education-related practices. Similar studies will be conducted in different countries and the comparison of the findings will contribute to the literature in terms of revealing the international trend.

\section{References}

Adem, M. (2008). Eğitim planlaması [Education planning] (4th ed.). Ankara: Ekinoks Publications.

Ainscow, M., Booth T. \& Dyson, A. (2006). Improving schools, developing inclusion. London: Routledge.

Alquraini, T., \& Dianne Gut, D. (2012). Critical components of successful inclusion of students with severe disabilities: Literature review. International Journal of Special Education, 27, 42-59.

Amor, A. M., Hagiwara M., Shogren K. A., Thompson J. R., Verdugo M. Á., Burke K. M. \& Aguayo, V. (2018). International perspectives and trends in research on inclusive education: a systematic review. International Journal of Inclusive Education, 1-19. doi:10.1080/13603116.2018.1445304

Barton, L. (1995). The politics of education for all. Support for Learning 10 (4), 156-160.

Booth, T. \& Ainscow, M. (2002). Index for inclusion. developing learning and participation in schools. 3rd ed. Bristol: CSIE.

Creswell, J. W. (2003). Research design: qualitative, quantitative and mixed methods approaches. California: Sage Publications.

Deng, M., Wang, S., Guan, W. \& Wang, Y. (2017). The development and initial validation of a questionnaire of inclusive teachers' competency for meeting special educational needs in regular classrooms in China. International Journal of Inclusive Education, 21 (4): 416-427.

Denzin, N. K., \& Lincoln, Y. S. (Eds.). (1994). Handbook of qualitative research. Thousand Oaks: Sage Publications.

Düşkün, Y. (2016). Türkiye'de ortaöğretimde kapsayıcı eğitim durum analizi [Inclusive education situation analysis in secondary education in Turkey]. İstanbul: Education Reform Initiative.

Ekiz. D. (2013). Bilimsel araştırma yöntemleri [Scientific research methods]. Ankara: Anı Publication.

European Commission/EACEA/Eurydice (2019). Integrating students from migrant backgrounds in to schools in europe: national policies and measures. Luxembourg: Publications Office of the European Union.

Florian, L. (2008). Inclusion: special or inclusive education: future trends. British Journal of Special Education, 35 (4), 202-208.

Guba, E. G., \& Lincoln, Y.S. (2005). Paradigmatic controversies, contradictions and emerging confluences. In. N. K. Denzin, \& Y. S. Lincoln (Ed.). The Sage Handbook of Qualitative Research (Third Edition). (pp. 191-216). Thousands Oaks, CA: SAGE Publications, Inc.

Gürgür, H. (2019). Kapsayıcı eğitim ve felsefi temelleri [Inclusive education and its philosophical foundations). In H. Gürgür \& S.Rakap (Ed.) Kapsayıcı Eğitim Özel Eğitimde Bütünleştirme [Inclusive Education Integrating Special Education], (1-16), Ankara: Pegem Publishing.

http://www.herkesicinegitim.org/urunler/kapsayici-egitim-literatur-incelemesi-2/ Retrieved at 22.05.2019 
Kaya, F. (2019). The importance of understanding in hermeneutic approach and positivism criticism. Dicle University Social Sciences Institute Journal, 11 (22), 271 - 280.

Keat, R., Urry, J. (2010). Social theory as science. London: Routledge.

Kırcaali İftar, G., \& Batu, S. (2005). Kaynaştırma [Inclusion]. Ankara: Kök Publishing.

Marshall, A. (1920). Principles of economics (8th ed.). London: Palgrave Macmillan.

McCart, A., Sailor, W., Bezdek, J. \& Satter, A. (2014). A Framework for inclusive educational delivery systems. Inclusion, 2 (4), 252-264.

Merriam, S. B., \& Tisdell, E. J. (2015). Qualitative Research: A Guide to Design and Implementation (Fourth Edition). CA: Jossey Bass.

Messiou, K. (2017). Research in the field of inclusive education: time for a rethink?. International Journal of Inclusive Education, 21 (2), 146-159. doi:10.1080/13603116.2016.1223184.

Miles, M. B., \& Huberman, A. M. (1994). An expanded sourcebook: qualitative data analysis (2nd. edition). Thousand Oaks, CA: SAGE Publications, Inc.

Nilholm, C., \& Göransson, K. (2017). What is meant by inclusion? An analysis of European and North American journal articles with high impact. European Journal of Special Needs Education, 32 (3), 437-451. doi:10.1080/08856257.2017.1295638.

OECD (Organisation for Economic Co-operation and Development) (2003). Education policy analysis diversity, inclusion and equity: Insights from special needs provision. Paris.

OECD (Organisation for Economic Co-operation and Development) (2016). PISA 2015 results: Excellence and equity in education (Vol. I). Paris.

Onwuegbuzie, A. J., \& Leech, N. L. (2004). Enhancing the interpretation of significant findings: The role of mixed methods research. The Qualitative Report, 9 (4), 770-792. Retrieved from https://nsuworks.nova.edu/tqr/vol9/iss4/10, 22.05.2019.

Patton, M. Q. (2015). Qualitative research and evaluation methods (4th ed.). Thousand Oaks, CA: Sage.

Polat, F. (2011). Inclusion in education: A step towards social justice. International Journal of Educational Development, 31(1), 50-58.

Robson, C. \& McCartan, K. (2016). Real world research: A resource for users of social research methods in applied settings (4th Edition). West Sussex: Wiley.

TBMM (Türkiye Büyük Millet Meclisi/Grand National Assembly of Turkey). (2018). Göç ve uyum raporu [Migration and integration report]. Aralı 2018, https://www.tbmm.gov.tr/komisyon/ insanhaklari/docs/2018/goc_ve_uyum_raporu.pdf

Türkiye Cumhuriyeti Anayasas1/ Constitution of Turkey (1982). Law Number: 2709, Government Journal: 9.11.1982, Retrieved from https://www.icisleri.gov.tr/illeridaresi/turkiye-cumhuriyetianayasasi, 22.05.2019

UNESCO (United Nations Educational, Scientific and Cultural Organizations) (2000). The Dakar framework for action. Education for all: Meeting our collective commitments. Dakar, Senagal

UNESCO (United Nations Educational, Scientific and Cultural Organizations) (2008). Inclusive education: the way of the future. Paris: Author.

UNESCO (United Nations Educational, Scientific and Cultural Organizations) (2009a). Policy guidelines on inclusion in education. France: UNESCO.

UNESCO (United Nations Educational, Scientific and Cultural Organizations) (2009b). 2009 World conference on higher education: the new dynamics of higher education and research for societal change and development (pp. 5-8). 
UNICEF (United Nations International Children's Emergency Fund) (2011). The right of children with disabilities to education: a rights-based approach to inclusive education. United Nations Children's Fund. Retrieved from www.unicef.org/ceecis.

United Nations Universal Declaration of Human Rights (1948). https://www.danistay.gov.tr/upload/insanhaklarievrenselbeyannamesi.pdf, Retrieved at 22.05.2019.

Ünal, L. I. (1996). Eğitim ve yetiştirme ekonomisi [Economics of education and training] (1st ed.). Ankara: Epar Publication.

Yıldırım A., \& Şimşek, H. (2013). Sosyal bilimlerde nitel araştirma yöntemleri [Qualitative research methods in the social sciences]. (9. Ed.). Ankara: Seçkin Publishing.

Yılmaz, S., \& Sarpkaya, R. (2017). Eğitimin temel kavramları [Basic concepts of education]. In A. Tanrıöğen \& R. Sarpkaya (Ed.), Eğitim Bilimine Giriş [Introduction to Education] (1-38). Ankara: Anı Publication.

Yücesoy Özkan, Ş., Kırkgöz, S. \& Besdere, B. (2019). From normalization to inclusive education: Historical background, In H. Gürgür \& S. Rakap (Ed.) Inclusive Education Integration in Special Education (17-53), Ankara: Pegem

Yücesoy Özkan, Ş., Kırkgöz, S. \& Besdere, B. (2019). Normalleştirmeden kapsayıcı eğitime: Tarihsel gelişim [From normalization to inclusive education: Historical background], In H. Gürgür \& S. Rakap (Ed.) Kapsayıcı Eğitim Özel Eğitimde Bütünleştirme [Inclusive Education Integration in Special Education], (17-53), Ankara: Pegem Publishing. 